\title{
The Stimulus of Impulse Buying Behavior on E-Commerce Shopping Festival: A Moderated-Mediated Analysis
}

Yulianto ${ }^{1 *}$,

Alexander Sisko ${ }^{2}$,

Evelyn Hendriana 3

1,2,3 Binus Business School Master Program, Business Management, Management

Department, Bina Nusantara University, Jakarta, Indonesia

\begin{tabular}{|c|c|}
\hline ARTICLE INFO & ABSTRACT \\
\hline $\begin{array}{l}\text { ISSN: 2723-1097 } \\
\text { Keywords: }\end{array}$ & $\begin{array}{l}\text { Studies on impulsive buying signify sales promotion and hedonic shopping } \\
\text { motivation as antecedents of impulsive buying behavior during the shopping festival. } \\
\text { The availability of different payment methods, such as credit cards and cash on } \\
\text { delivery, can make consumers more impulsive. Despite the potential effect of payment } \\
\text { methods on impulsive buying behavior, only a few studies are looking at this variable. }\end{array}$ \\
\hline $\begin{array}{l}\text { Attitude towards sales } \\
\text { promotion; COD payment; } \\
\text { Hedonic motivation; } \\
\text { Impulsive buying behavior; } \\
\text { Sales promotion }\end{array}$ & $\begin{array}{l}\text { Hence, this study aims to examine the moderated-mediation effect of attitude toward } \\
\text { shopping festivals and cash-on-delivery payment methods in the relationship between } \\
\text { sales promotion, hedonic shopping motivation, and impulsive buying behavior. } \\
\text { Purposive sampling was applied to select samples that resulted in } 210 \text { valid responses. } \\
\text { Data were analyzed using PLS-SEM that indicated an indirect effect of the perceived } \\
\text { low price on impulsive buying behavior through attitude toward sales promotion } \\
\text { during online shopping festivals. Other elements related to sales promotion such as } \\
\text { perceived perishability and scarcity did not affect attitude toward sales promotion and } \\
\text { impulsive buying behavior. In contrast, hedonic shopping motivation had a direct } \\
\text { effect on the impulsive buying behavior and an indirect effect via attitude towards } \\
\text { sales promotion. Our finding only supported the moderating role of cash on delivery } \\
\text { payment method in the relationship between hedonic shopping motivation and } \\
\text { impulsive buying behavior. These findings provide insights to businesses in applying } \\
\text { for sales promotion and utilizing customers' hedonic shopping motivation to } \\
\text { maximize their sales during the shopping festival. }\end{array}$ \\
\hline
\end{tabular}

\section{Introduction}

The e-commerce value transaction has significantly increased since 2014, and it is estimated at US\$ 5.695 billion in 2022 and US\$ 6.542 billion in 2023 in the global transaction (Statista, 2020). That phenomenon is supported by various promotional events such as online shopping festivals. Online shopping festival, one of the busiest and most captivating days for all e-commerce was known in many different names, Singles' Day in China, Cyber Hot Days in Korea, Diwali Festival in India, Black Friday, Cyber Monday in the USA, and Harbolnas in Indonesia. During the online shopping festival, e-commerce carries out various promotion programs to attract customers and increase sales. Those promotion programs mainly affect customer emotions and behavior that are reflected through impulsive buying behavior (Vannisa et al., 2020)

Journal of Business and Management Review Vol. 2 No. 102021 Page 692-714

DOI: $10.47153 /$ jbmr210.2152021

*Corresponding Author

Email address: julez1801@gmail.com 
due to limited purchase time, a limited number of products, and very low prices. This euphoria raises customers' intention to shop, especially for those who do not want to lose the opportunity to get the product at its lowest price. Liu et al. (2019) found that the customers' shopping behavior was influenced by hedonic shopping motivation in online shopping festivals. The feeling of fun and pleasure triggers their hedonic shopping motivation, which eventually directs their shopping behavior during the online shopping festival.

Iyer et al.'s (2020) meta-analysis shows various internal and external factors that affect impulsive buying behavior. The internal factors include consumer traits (sensationseeking, impulsive buying tendency, self-identity), purchase motivation (utilitarian motives, hedonic motives), resources (physical, time, financial); while the external factors consist of marketing stimuli such as price discounts, sales promotions, store promotions, store atmosphere, and products. Among these factors, the psychological factors have a substantial effect in triggering impulsive buying behavior (Rook, 1987). A study in Dubai found that impulsive buying behavior was strongly influenced by promotional factors and hedonic shopping motivation (Prashar et al., 2015).

Several studies have focused on the effect of sales promotion on impulsive buying behavior during shopping festivals. Kwon and Brinthaupt (2015) found that impulse buying behavior was caused by purchase motivation, characteristics, and consumer experiences during the Black Friday festival in the U.S. In South Korea, Jun (2018) found that economic value, emotional value, and product variety positively affected impulsive buying behavior at Cyber hot day festivals. Similarly, Khanna and Sampat (2015) revealed that low prices and product specifications were the key factors for Indian consumers to shop impulsively during the Diwali Festival. In Indonesia, consumer perceptions of the online sales promotion program, namely perceived perishability and perceived scarcity, influenced impulsive buying behavior during flash sales on e-commerce (Vannisa et al., 2020).

Impulsive buying behavior is also influenced by hedonic shopping motivations (Nandha et al., 2017; Iyer et al., 2020). Hedonic shopping motivation is a critical factor that influences shopping behavior during online shopping festivals in China (Liu et al., 2019). In the context of impulsive buying behavior, hedonic shopping motivation was found to have a positive effect on impulsive buying behavior (Setyaningrum et al., 2016; Andani \& Wahyono, 2018; Kempa et al., 2020). However, these studies did not look at the dimensionality of hedonic shopping motivation. Cavușoğlu, Demirag, and Durmaz (2020) found that the dimensions of hedonic shopping motivation, namely novelty, fun, praise from others, escapism, and social interaction, had significant effects on purchase intention. An understanding of the dimensions of hedonic shopping motivation will give a deeper understanding of the effect of hedonic shopping motivation on impulsive buying behavior during shopping festivals.

In Indonesia, the online shopping festival is named Hari Belanja Online Nasional (Harbolnas hereafter). Its transaction value achieved its peak on December 12, 2020, 
with an accumulated transaction value of IDR 11.6 trillion. Despite its significant value, research on perceptions of sales promotions and hedonic shopping motivation as factors that influence impulsive buying behavior during Harbolnas is limited. Previous research on Harbolnas only focuses on the effect of service quality on customer satisfaction for delivery services (Nugroho \& Magnadi, 2018); the influence of price, product, convenience, security on purchasing decisions (Pratama, 2019); and the influence of price and website quality on purchasing decisions (Rahmawan \& Hanifa, 2016).

The availability of particular payment methods may stimulate consumers to be more impulsive when shopping. Payment methods using credit cards are found to have a positive impact on impulsive buying behaviors in developed countries (Robert \& Jones, 2001; Arslan, 2015; Badgaiyan \& Verma, 2015; Rajput et al., 2016). However, consumers in emerging countries face security and privacy issues when using a credit card in online shopping (Hawk, 2004). As a result, they feel more secure and comfortable using cash payments after receiving the product (Rouibah, 2015; Wu, Deng, \& Cui, 2019). Cash on delivery (COD hereafter) as an alternative payment in recent years has increased and is widely favored in Gulf Cooperation Council (GCC) countries such as India, Thailand, Vietnam, and Poland. Tandon and Kiran (2018) found that COD mediates hedonic shopping motivation and perceived low price towards purchase intention. COD also moderates utilitarian and hedonic motivations towards online purchase intention (Hameed \& Deeb, 2020). In Indonesia, COD and credit cards are the most frequently used payment methods in e-commerce transactions (E-commerce Statistics, 2019). However, the previous study did not explicitly discuss the moderating role of COD in the context of impulsive shopping behavior during online shopping festivals. This study aims to fill the gap by examining the effect of customer perceptions of sales promotion and hedonic shopping motivation on the impulsive buying behavior and the moderating role of COD in these relationships.

\section{Literature Review}

\section{Stimulus-Organism-Response (SOR) Theory}

This study uses the stimulus-organism-response theory as the basis for explaining impulsive buying behavior. In 1953, Hovland et al. proposed the stimulus-organismresponse hypothesis, which detailed how a stimulus results in a given reaction on an individual. A stimulus can be anything in the environment such as store ambiance, product design, advertising, and social considerations. These stimuli can evoke consumers' emotion, known as the organism, which later triggers an individual's ultimate action, reaction, or response (Chang et al., 2011).

Jacoby (2002) explains that the surrounding environment stimulates learning processes that occur implicitly and without awareness. This process is influenced by sociocultural factors, such as culture, sub-culture, ethnicity, religion, social class, and group membership. Next, the stimulus may touch an individual's self-awareness 
(Zaltman, 2000), which includes an individual's motivation, mood, perception, and cognition. Later, it generates stimulus-response such as reflex behavior of chemically induced behavioral changes. The last component is the consequences of the stimuli and responses obtained and the behavioral tendencies/behavioral changes that occur. Therefore, this theory explains in detail the factors that trigger impulsive buying behavior.

This theory can explain the phenomena of consumer behavior during online shopping festivals, the stimulus of the sales promotion program induces consumer attitude towards the online shopping festival, which eventually causes them to shop impulsively. This study also includes internal factor, which is hedonic shopping motivation, and payment method into the model.

\section{Impulsive Buying Behavior}

Impulsive buying behavior may be seen as an unplanned buy when customers sense a sudden drive that frequently is powerful and continuous to buy something quickly (Rook, 1987). Iyer et al. (2020) and Phrasar et al. (2014) indicate that impulsive buying behavior may be triggered by internal aspects (i.e., personality, characteristics, buying motivation, and individual's resources) and external factors (i.e., promotions, in-store impacts, product-related influences, and convenience of payment such as payment options via credit card, bank transfers, virtual/e-mail).

Some studies found a significant impact of sales promotion on impulsive buying behavior (Omid, 2016; Kempa et al., 2020; Akram et al., 2017; Mathur \& Bhakar, 2019). Vanissa et al. (2020) reported similar findings when tested the relationship in the ecommerce context during flash sale events. The results are consistent with research conducted in other Asian nations, such as China (Akram et al., 2017) and Pakistan (Hussain \& Siddqui, 2019). In addition, in numerous countries, including Indonesia (Amanah \& Pelawi, 2015; Nandha et al., 2017; Andani \& Wahono, 2018), the role of hedonic shopping motivation on impulsive buying behavior has also been exercised (Dewi et al., 2017). The mode of payment is one of these factors. Prior research indicates significant influences of credit/debit cards on impulsive buying behavior (Akram et al., 2018). Although consumers in developing nations prefer the COD payment option due to relatively poor data security levels, there is currently not much research on its effect on impulsive buying behavior.

\section{Sales Promotion}

Kotler and Keller (2016) define promotion as the process by which businesses achieve their advertising and marketing objectives through sales promotion (sales promotion), marketing (advertising), salesforce, public relations, and direct marketing. Shamout (2016) discovered that all promotional tools, including coupons, samples, price reductions, and buy one get one free offer, had a substantial influence on brand switching behavior, customer loyalty, and consumer purchase decisions. In addition, 
sales promotion programs can influence purchasing decisions, including impulsive shopping behavior. During shopping festivals, consumer perceptions toward the sales promotion programs are related to the number of the quantity offered, time limit, and price. As reported by Vannisa et al. (2020), these three elements, namely perceived perishability, perceived scarcity, and perceived low price significantly affect impulsive buying behavior.

Perceived perishability refers to the deterioration of goods with a fixed or desired useful life after a certain period (Gupta et al., 2003), and it conveys the time constraint or time-sensitive nature of a product or program whose value will expire once it reaches a certain threshold (Byun \& Sternquist, 2008). Marketers frequently use semantic terms like "quick, time-limited" and "while supplies last" (Byun \& Sternquist 2011), or "one day sale only" (Aggarwal \& Vaidyanathan, 2003). This perception is critical for increasing the efficacy of sales promotion programs (Byun \& Sternquist 2012), which effectively reduce the possibility of customers find replacement products (Aggarwal \& Vaidyanathan, 2003). Promotions carried out by reducing prices within a specific time limit had a positive effect on impulsive shopping behavior (Kempa et al., 2020), particularly during sale promotion programs (Vannisa et al., 2020).

Scarcity is a state of imbalance between supply and demand that results in scarcity and competition for resources (Kristofferson et al., 2017). In this study perceived scarcity refers to the scarcity of the number of products, thus, it makes it more economically valuable (Bertens, 2018). Companies purposefully create the state of a scarcity of goods, one of which is through generating an impression of scarcity through promotion and marketing (Kristofferson et al., 2017; Cialdini, 2009; Gitlin, 2007). They sell highly coveted items in limited numbers and for a limited promotional period at steep discounts during this festival (Kristofferson et al., 2017). It will influence consumers' attitudes and emotions so that they perceive each other as rivals to obtain the limited product (Morales et al., 2014). They feel more pressure to buy the products as soon as possible (Cook \& Yurchisin, 2016; Byun \& Sternquist, 2011; Tokatli, 2008).

Price is a significant determinant of purchase decisions (in \& Suh, 2005). Calvo and Mangin (2017) define perceived low price as a consumer's evaluation of a product's affordability. It influences how buyers perceive the value of a product (Beneke et al., 2013; Snoj et al., 2004). Significantly lower prices than usual costs can entice people to purchase items offered by marketers (Cook \& Yurchisin, 2016) and as a significant aspect that contributes to consumer hoarding behavior (Byun \& Sternquist, 2008). Price is a determining factor that influences consumer attitudes towards sales promotion (Beneke et al., 2013) since they see the affordability of a product (Calvo \& Mangin, 2017). During shopping festivals, consumers anticipated getting the products at a lower price, although they realized that this program was only held for a limited time and a limited number of products offered while there were a lot of consumers. Hence, the following hypotheses are proposed: 
H1: Perceived perishability has a positive influence on attitudes toward sales promotion.

H2: Perceived scarcity has a positive influence on attitudes toward sales promotion.

H3: Perceived low prices have a positive influence on attitudes toward sales promotion.

The Perceived perishability and perceived scarcity has positive and significant effects on attitudes towards promotional programs and impulsive shopping behavior held by fashion retailers (Cook \& Yurchisin, 2016) and during the flash sale programs (Vanissa et al., 2020). The perceived low price has a significant effect on attitude towards sales promotion (Amara \& Kchaou, 2014; Badgaiyan \& Verma, 2015; Omid, 2016; Muna et al., 2017) and impulsive buying behavior (Amanah \& Pelawi, 2015). Thus, it can be hypothesized that:

H4: Perceived perishability has a positive influence on impulsive buying behavior.

H5: Perceived scarcity has a positive influence on impulsive buying behavior.

H6: Perceived low price has a positive influence on impulsive buying behavior.

\section{Hedonic Shopping Motivation}

Individuals shop to satisfy their needs which is urged either by utilitarian or hedonic shopping motivation (Kotler \& Keller, 2016). Utilitarian shopping motivation comes from the external stimuli or functional reason of merchandise attributes. Hedonic shopping motivation is triggered by emotional satisfaction attributes such as novelty, fun, praise from others, escapism, and social interaction (Çavusoglu et al., 2020). Recent research showed that these five factors had a favorable impact on impulsive shopping behavior (Dey \& Srivastava, 2017).

Novelty is significant in influencing purchasing decisions of young consumers (Madahi et al., 2012). When they discover new products, they tend to buy impulsively (Phau \& Lo, 2004). Shopping impulsively is driven by curiosity to know the novelty of a product (Harmancioglu et al., 2009). Fun is giving an instant indulgence associated with impulse buying (Rook, 1987) as consumers feel the excitement and a unique experience during shopping ( $\mathrm{Yu} \&$ Bastin, 2010). Impulsive buying behavior in Indian young consumers has been driven by pleasure (Dey \& Srivastava, 2017). They found pleasure when shopping for discounted products (Çavusoglu et al., 2020). Consumers feel that shopping brings happiness and joy to reduce pain or pressure within them (Yu \& Bastin, 2010). Escapism is a significant factor that influences the purchase of a product (Scarpi et al., 2014). And they do an impulsive purchase behavior because they want to escape from negative emotions or boredom $(\underline{\mathrm{Xu}, 2007})$.

Hedonic shopping motivation is an important predictor of online shopping behavior (Burke, 1999) and attitudes towards sales promotional programs (Childers et al., 2001; 
Chung et al., 2017). Khare et al. (2014) found that hedonic shopping motivation influenced consumer attitudes towards sales promotion at retail malls in India. Shopping festivals offer huge discounted products and are considered to provide fun, new experiences. So they can escape from boredom and daily routines and affect consumer attitudes towards the promotional program. Hence, we posit that:

H7: Hedonic shopping motivation has a positive influence on attitudes toward sales promotion.

Hedonic motivation also encourages a consumer to spend excessively to get pleasure (Amanah \& Pelawi, 2015), explore new worlds, and escape from boredom (Dey \& Srivastava, 2017) by considering shopping activities as interesting activities and significantly influence impulsive shopping behavior (Kosyu, 2014). When consumers have hedonic motivations, shopping festivals are often seen as an opportunity to fulfill their desires, so that they are motivated to purchase impulsively. The relationship is presented as follows:

H8: Hedonic shopping motivation has a positive influence on impulsive shopping behavior.

\section{Attitude toward the Promotional Program}

Promotional programs are often designed in such a way as to prompt a quick purchase decision (Genchev \& Todorova, 2017) and aiming to create a consumer's attitude. Consumers' attitudes on sales promotional programs determine their behavior and it is positively influencing impulsive buying behavior (Vannisa et al., 2020). Sales promotion programs, such as the Harbolnas festival, are considered as having the potential to deliver greater advantages to customers because they can buy the product at its lower price. This will result in customers having a favorable view about the program, as demonstrated by the following hypothesis:

H9: Attitudes toward sales promotion have a positive influence on impulsive buying behavior.

\section{Payment Method}

Nowadays, e-commerce provides several payment methods to ease consumers. In addition to e-wallet, credit cards, e-banking, and e-check, COD is a popular method of payment in today's e-commerce operations. Studies in developed nations show that credit cards can affect impulse purchases in online sales (Akram et al., 2018) as consumers can delay payments or make payments in instalments. In developing countries, consumers feel more comfortable paying in cash after receiving the product (Rouibah, 2015; Wu et al., 2019) due to trust, security, and privacy issues (Halaweh, 2017; Anjum \& Chai, 2020). COD is preferred by Indian (Parmar \& Chauhan, 2018) and Indonesian consumers (Siregar \& Rini, 2019). Putri et al. (2019) found that cash on delivery is preferred over 4 other payment methods, namely point of share, prepaid, 
virtual accounts, and credit cards. It is just slightly below bank transfer, which is probably because the COD method was not available in some e-commerce at that time. Ilmalana (2012) and Mathur \& Bhakar (2019) found that COD affected impulse buying behavior as this payment method is perceived safer than another payment method as consumers pay after they receive the merchandise. This argument leads to the following hypothesis:

H10: COD has a positive influence on impulsive buying behavior.

COD can reduce the difficulty when shopping online (Tandon \& Kiran, 2018). COD payment method may moderate the relationship between hedonic shopping motivation and purchase intention (Hameed \& Deeb, 2020). Consumers who do not have a credit card or want to protect their data (Halaweh, 2018) are willing to pay more when they use the COD method (Wu et al., 2019). Thus, the hypothesis to be tested is as follows:

H4a: COD moderates the relationship between perceived perishability and impulsive buying behavior.

H5a: COD moderates the relationship between perceived scarcity and impulsive buying.

H6a: COD moderates the relationship between perceived low prices and impulsive buying behavior.

H8a: COD moderates the relationship between hedonic shopping motivation and impulsive buying behavior.

H9a: COD moderates the relationship between attitude toward sales promotion and impulsive buying behavior.

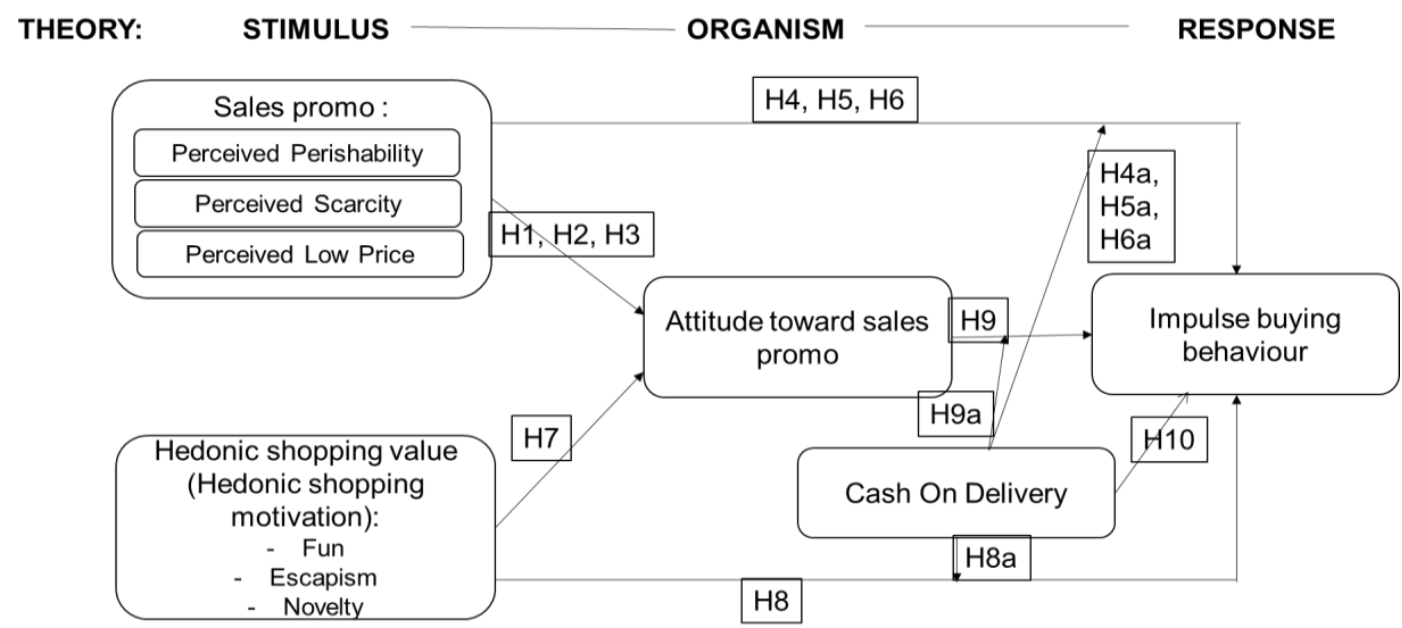

Figure 1. Research Model 


\section{Method}

The population of this study is the e-commerce customers in Indonesia who participated in the Harbolnas festival on December 12, 2020. An online survey using a Google form was performed to collect data. From 497 responses received, only 42 percent ( 210 data) could be processed further. The 287 responses were not included as the respondents did not participate in shopping festivals or gave inconsistent answers.

All items were adopted from literature. Each dimension of consumers' perception toward the sales promotion was measured by four items. Items of perceived perishability were taken from Gupta and Gentry (2019) and Vannisa et al. (2020); perceived scarcity from Byun and Sternquist (2012), Chung et al. (2015), Gupta and Gentry (2019), and Vannisa et al. (2020); and perceived low price from Cook and Yurchisin (2016). Each dimension of hedonic shopping motivation was measured by four items adapted from Dey \& Srivastava (2017), and Çavusoglu et al. (2020). Attitude towards sales promotion was measured by five items from Mihic \& Milakovic (2017) and Vannisa et al. (2020). Five items measuring COD were adopted from Badgaiyan and Verma (2015), Halaweh (2017), Anjum and Chai (2020), and Tandon and Kiran (2018). Five items of impulsive buying behavior were taken from Mu and Moon (2016), Zheng et al. (2019), and Zheng and Lee (2016). All items were measured by a 5-point Likert scale. Partial least square structural equation modeling (PLS-SEM) was used to test the hypotheses.

\section{Result and Discussion}

All items fulfilled the convergent validity requirement with factor loadings between 0.569 and 0.948 , and AVEs between 0.605 and 0.838 (Table 1). A discriminant validity test was conducted to ascertain the construct dis not overlap with other construct, which was reflected through the square root of AVE of each variable that was greater than its correlation with other variables (Table 3). The reliability was indicated by the Cronbach's alpha and composite reliability of all variables above 0.7 as presented in Table 1 .

Table 1. Convergent Validity and Reliability

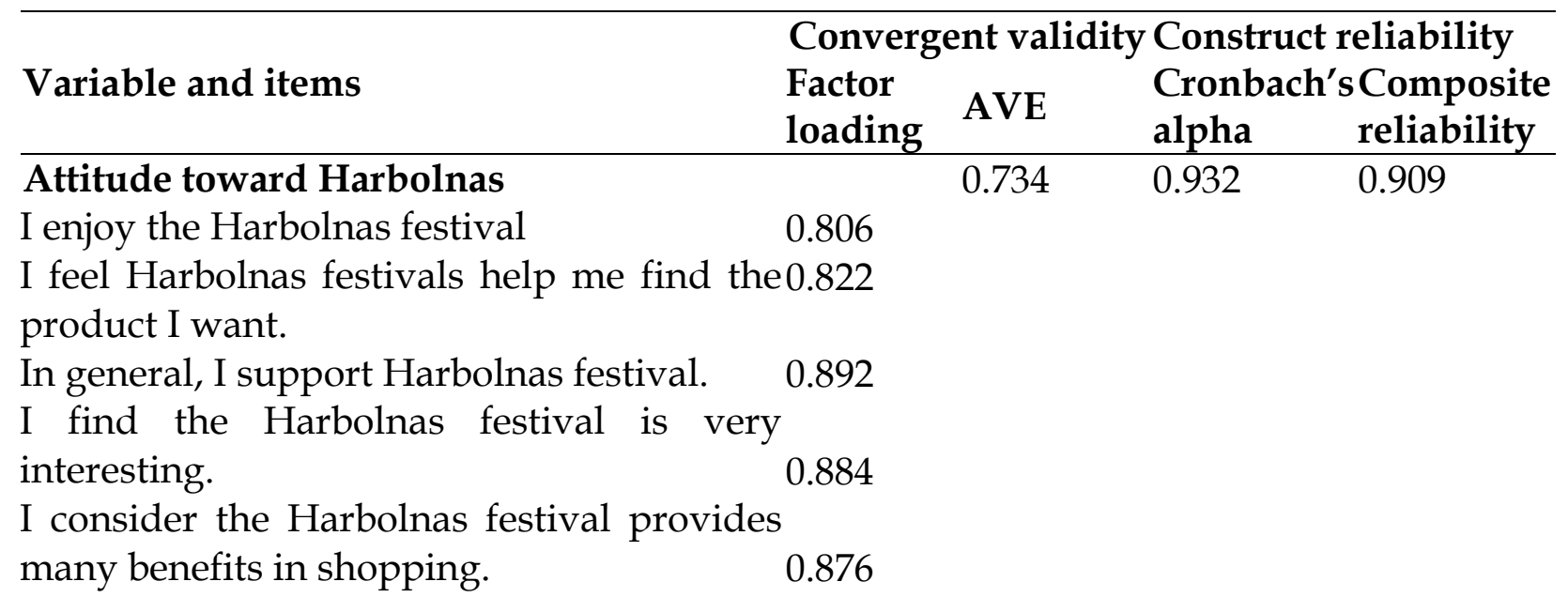




\begin{tabular}{lllll}
\hline \multirow{2}{*}{ Variable and items } & \multicolumn{3}{c}{ Convergent validity Construct reliability } \\
& $\begin{array}{l}\text { Factor } \\
\text { loading }\end{array}$ & AVE & $\begin{array}{l}\text { Cronbach's Composite } \\
\text { alpha }\end{array}$ \\
& & 0.838 & 0.963 & 0.952 \\
\hline COD Payment & & &
\end{tabular}

When shopping online, I usually use the 0.948

COD payment method.

Sometimes, I cancel my purchase if there is 0.887 no COD payment method.

Before ordering a product, I check the availability of COD payment method.

I prefer to use COD when buying products

online.

COD increases my confidence when shopping.

Escapism

$\begin{array}{lll}0.806 & 0.943 \quad 0.919\end{array}$

I can escape from reality while shopping. $\quad 0.876$

I feel excited taking risks while shopping. 0.883

I can forget my troubles during shopping at

Harbolnas festivals.

Shopping is a way to relieve pressure from

myself.

Fun

$0.723 \quad 0.912$

0.872

This shopping is a wonderful experience. 0.794 Compared to others, spending time on 0.864 shopping is so Enjoyable.

During shopping at Harbolnas festival, I feel0.880 excited.

This shopping activity makes me happy. $\quad 0.862$

Impulse Buying Behaviour

Harbolnas Festival is good for encouraging

consumers to buy products impulsively or 0.569

spontaneously.

During the Harbolnas festival, I tend to buy

products impulsively.

When the Harbolnas festival is held, I tend

to buy products in a hurry.

During the Harbolnas festival, I tend to buy

products that I didn't plan for.

During the Harbolnas festival, my decision

could be described as "buy now, think 0.813 later".

Perceived Low Price

$\begin{array}{lll}0.605 & 0.891 & 0.837\end{array}$

The product price at Harbolnas festival is 0.812

$\begin{array}{lll}0.734 & 0.883 & 0.830\end{array}$ inexpensive. 


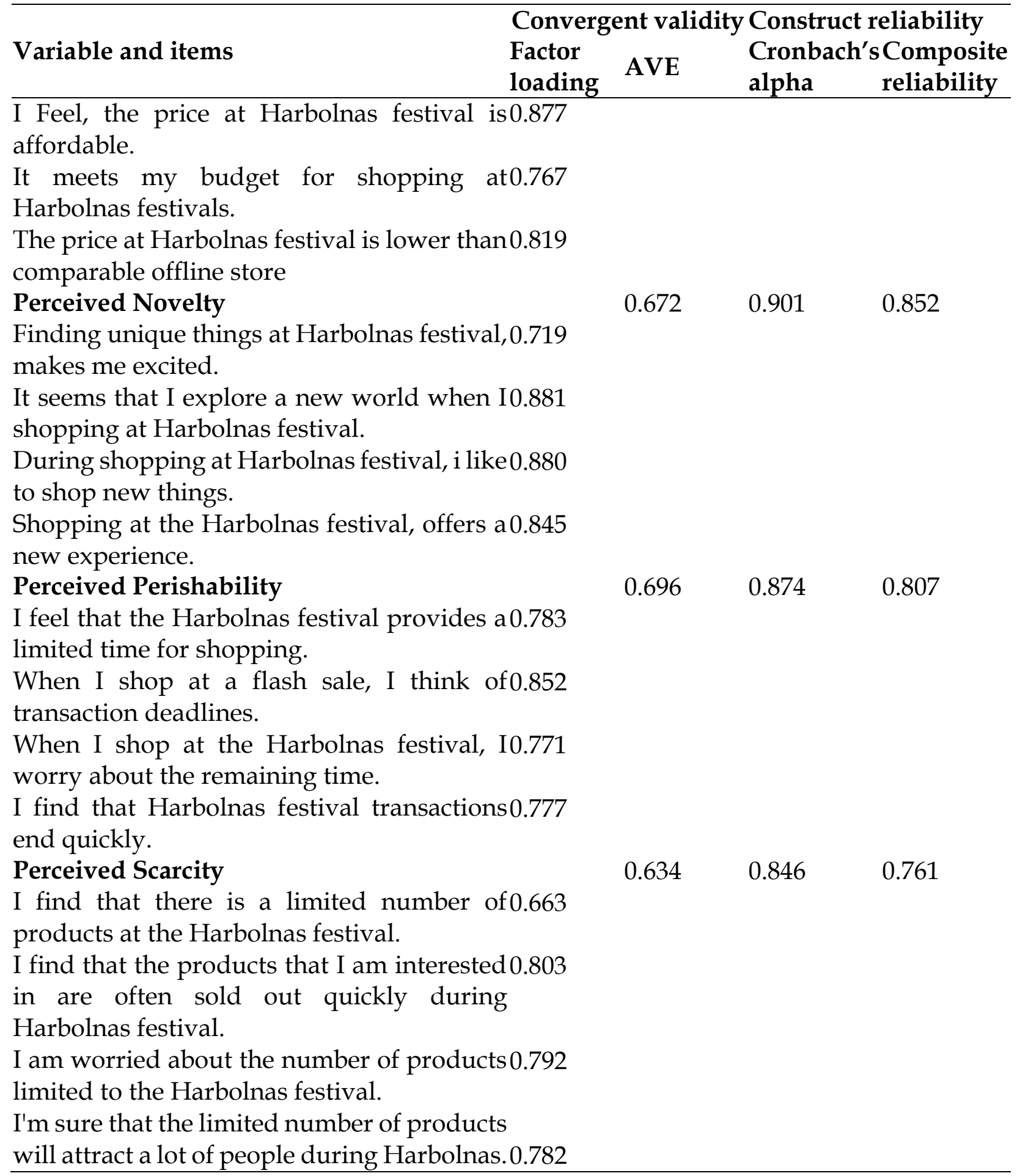

Table 2. Fornell-Larcker Discriminant Validity

\begin{tabular}{lllllllllll}
\hline & AT & COD & ES & FU & HED & IBB & LP & NO & PE & SC \\
\hline AT & 0.857 & & & & & & & & & \\
COD & 0.095 & $\mathbf{0 . 9 1 5}$ & & & & & & & & \\
\end{tabular}




\begin{tabular}{lllllllllllll} 
ES & 0.442 & 0.313 & $\mathbf{0 . 8 9 8}$ & & & & & & & \\
FU & 0.653 & 0.265 & 0.744 & $\mathbf{0 . 8 5 0}$ & & & & & & \\
HED & 0.613 & 0.325 & 0.882 & 0.930 & $\mathbf{0 . 7 6 5}$ & & & & & \\
IBB & 0.456 & 0.119 & 0.377 & 0.454 & 0.458 & $\mathbf{0 . 7 7 8}$ & & & & \\
LP & 0.642 & 0.188 & 0.377 & 0.606 & 0.561 & 0.398 & $\mathbf{0 . 8 2 0}$ & & & \\
NO & 0.537 & 0.291 & 0.587 & 0.724 & 0.854 & 0.388 & 0.515 & $\mathbf{0 . 8 3 4}$ & & \\
PE & 0.342 & 0.145 & 0.221 & 0.404 & 0.384 & 0.321 & 0.297 & 0.408 & $\mathbf{0 . 7 9 6}$ & \\
SC & 0.285 & 0.137 & 0.122 & 0.320 & 0.293 & 0.317 & 0.340 & 0.351 & 0.507 & $\mathbf{0 . 7 6 2}$ \\
\hline
\end{tabular}

As presented in Table 3, before the inclusion of moderation effects, the influences of perceived perishability on attitude toward sales promotion $(\beta=0.086$, $p$-value $=0.085)$ and impulsive buying behavior $(\beta=0.078$, $p$-value $=0.159)$ were insignificant, which did not support $\mathrm{H} 1$ and H4. In contrast, perceived scarcity had a significant direct influence on impulsive buying behavior $(\beta=0.129$, $p$-value $=0.046)$, but insignificant on attitude toward sales promotion was insignificant $(\beta=-0.004$, $\mathrm{p}$-value $=0.476)$. Hence, $\mathrm{H} 2$ was rejected while $\mathrm{H} 5$ was supported. Perceived low price significantly influenced attitude towards sales promotion $(\beta=0.429$, $\mathrm{p}$-value $=0.000)$, which supports H3. Nevertheless, it did not influence impulsive buying behavior $(\beta=0.073$, p-value $=0.166)$, which did not support H6. Hedonic shopping motivation had a significant influence on attitude toward sales promotion $(\beta=0.342$, $p$-value $=0.000)$ and impulsive buying behavior $(\beta=0.227$, $p$-value $=0.009)$, which support $\mathrm{H} 7$ and $\mathrm{H} 8$. The effect of attitude toward sales promotion on impulsive buying behavior was significant $(\beta=0.207, p$-value $=0.010)$ that gave support to H9. Last, COD did not influence impulsive buying behavior $(\beta=-0.018$, $p$-value $=0.395)$ so that H10 was rejected.

Table 3. Hypothesis Testing

\begin{tabular}{|c|c|c|c|c|c|c|}
\hline \multirow[t]{2}{*}{ Path } & \multicolumn{3}{|c|}{$\begin{array}{l}\text { Without moderation effect } \\
\mathrm{R}^{2} \mathrm{AT}=0.512 \\
\mathrm{R}^{2} \mathrm{IB}=0.292\end{array}$} & \multicolumn{3}{|c|}{$\begin{array}{l}\text { With moderation effect } \\
R^{2} A T=0.512 \\
R^{2} I B=0.341 \\
\text { Changes of } R^{2} I B=0.049 \\
f^{2} I B=0.074\end{array}$} \\
\hline & $\boldsymbol{\beta}$ & S.E. & p-value & $\beta$ & S.E. & p-value \\
\hline H1: PE $\rightarrow$ AT & 0.086 & 1.374 & 0.085 & 0.086 & 1.350 & 0.088 \\
\hline $\mathrm{H} 2: \mathrm{SC} \rightarrow \mathrm{AT}$ & -0.004 & 0.061 & 0.476 & -0.004 & 0.060 & 0.476 \\
\hline H3: LP $\rightarrow$ AT & 0.426 & 6.727 & 0.000 & 0.426 & 6.632 & 0.000 \\
\hline H4: PE $\rightarrow$ IB & 0.078 & 0.998 & 0.159 & 0.072 & 0.955 & 0.170 \\
\hline $\mathrm{H} 5: \mathrm{SC} \rightarrow \mathrm{IB}$ & 0.129 & 1.684 & 0.046 & 0.096 & 1.244 & 0.107 \\
\hline
\end{tabular}
703 | P a g e Article's contents are provided on a Attribution-Non Commercial 4.0 Creative commons license.To see the complete license contents, please visit http://creativecommons.org/licenses/by-nc/4.0/ 


\begin{tabular}{|c|c|c|c|c|c|c|}
\hline \multirow[t]{2}{*}{ Path } & \multicolumn{3}{|c|}{$\begin{array}{l}\text { Without moderation effect } \\
\mathrm{R}^{2} \mathrm{AT}=0.512 \\
\mathrm{R}^{2} \mathrm{IB}=0.292\end{array}$} & \multicolumn{3}{|c|}{$\begin{array}{l}\text { With moderation effect } \\
\mathrm{R}^{2} \mathrm{AT}=0.512 \\
\mathrm{R}^{2} \mathrm{IB}=0.341 \\
\text { Changes of } \mathrm{R}^{2} \mathrm{IB}=0.049 \\
\mathrm{f}^{2} \mathrm{IB}=0.074\end{array}$} \\
\hline & $\bar{\beta}$ & S.E. & p-value & $\beta$ & S.E. & p-value \\
\hline H6: LP $\rightarrow$ IB & 0.073 & 0.970 & 0.166 & 0.038 & 0.493 & 0.311 \\
\hline H7: HED $\rightarrow$ AT & 0.342 & 5.149 & 0.000 & 0.342 & 5.131 & 0.000 \\
\hline H8: HED $\rightarrow$ IB & 0.227 & 2.361 & 0.009 & 0.292 & 3.171 & 0.001 \\
\hline $\mathrm{H9:}$ AT $\rightarrow$ IB & 0.207 & 2.337 & 0.010 & 0.209 & 2.684 & 0.004 \\
\hline H10: COD $\rightarrow$ IB & -0.018 & 0.265 & 0.395 & -0.069 & 0.998 & 0.159 \\
\hline H4a: $\mathrm{PE}^{*} \mathrm{COD} \rightarrow \mathrm{IB}$ & & & & 0.008 & 0.093 & 0.463 \\
\hline H5a: SC ${ }^{*} \mathrm{COD} \rightarrow \mathrm{IB}$ & & & & 0.013 & 0.160 & 0.437 \\
\hline H6a: $\mathrm{LP}^{*} \mathrm{COD} \rightarrow \mathrm{IB}$ & & & & -0.036 & 0.460 & 0.323 \\
\hline H8a: $\mathrm{HED}^{*} \mathrm{COD} \rightarrow \mathrm{IB}$ & & & & 0.195 & 2.405 & 0.008 \\
\hline H9a: $\mathrm{AT}^{*} \mathrm{COD} \rightarrow \mathrm{IB}$ & & & & 0.063 & 0.798 & 0.213 \\
\hline
\end{tabular}

Note: PE: perceived perishability, SC: perceived scarcity, LP: low price, HED: hedonic shopping motivation, AT: attitude toward shopping festival, COD: cash on delivery, $\mathrm{IB}=$ impulsive buying behavior

The product indicator approach was used to test the moderation effect to maximize the moderating variable (Hair et al., 2017). The R-square value increased by 0.049 that resulted in an effect size of 0.074 , which is categorized as a significant small effect. The presence of moderation effect caused the effect of perceived scarcity on impulsive buying behavior to become insignificant $(\beta=0.096$, $p$-value $=0.107)$. This study only found a significant moderating effect of COD in the relationship between hedonic shopping motivation and impulsive buying behavior $(\beta=0.195, p$-value $=$ 0.008), which only H8a was supported. Figure 1 shows the slope analysis. Respondents who had higher hedonic shopping motivation tended to be more impulsive during the online shopping festival when there was an option of COD. This trend was indicated by a sharper slope on the curve with a dotted line indicating the availability of the COD payment method as presented in Figure 2.

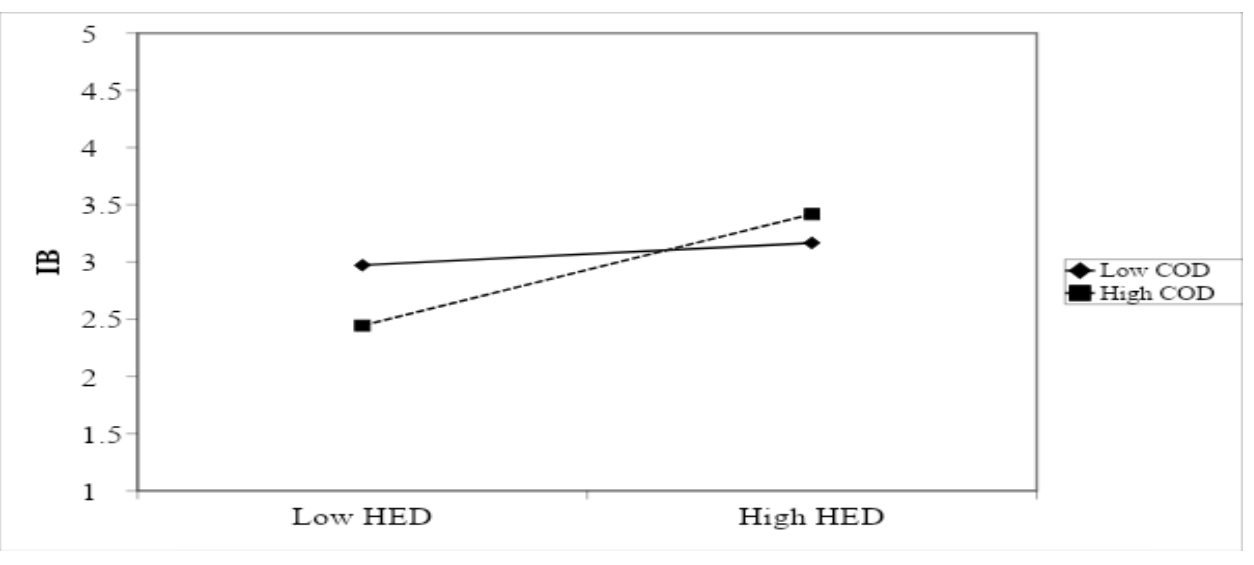

704 | P a g e Article's contents are provided on a Attribution-Non Commercial 4.0 Creative commons license.To see the complete license contents, please visit http://creativecommons.org/licenses/by-nc/4.0/ 


\section{Figure 2. Slope Analysis for the moderating effect}

\section{Discussion}

The findings confirm the applicability of SOR theory in which several elements of online sales promotion have a direct impact on the response that is reflected through impulsive buying behavior and indirectly through attitude toward the sales promotion. These elements are perceived scarcity and perceived low price.

Perceived scarcity is a stimulus given during sales promotion activities. The more limited the quantity offered during the shopping festival, the more likely the customers to shop impulsively. This finding supports previous studies by Cook and Yurchisin (2016), Goetha (2020), and Ismaya (2018). Contrary to the prediction, perceived scarcity only has a direct effect on impulsive buying behavior as its effect on attitude toward sales promotion is insignificant. As mentioned by Verhallen and Robben (1994), perceived scarcity affects customers' perception toward the value of the products. It seems that Indonesian customers have more interest in specific products offered at a fantastic price. For instance, smartphones are offered at IDR 100,000 , which is below USD10. As there are only a small number of smartphones offered at that price during Harbolnas, customers are competing with each other to grab the product. As such, it directly stimulates impulsive buying behavior, not through attitude toward the sales promotion.

Unlike perceived scarcity that directly affects impulsive buying behavior, perceived low price has an indirect positive effect on impulsive buying behavior through attitude toward the sales promotion. This finding is consistent with Badgaiyan and Verma (2015), Omid (2016), as well as Muna et al. (2017). Cook and Yurchisin (2016) stated that low prices positively influence customer attitude and encourages merchandise hoarding . During Harbolnas, only a few products are offered at the limited quantity at a very low price. The rest of the merchandise is offered at a discounted price but the quantities are quite abundant. When customers see there are plenty of products at the discount price, they are likely to consider the sales promotion program is worthy to get their attention and engage with the program. If they like the shopping festival, they will be more likely to buy the product immediately.

The only element of sales promotion that does not significantly influence attitude toward sales promotion programs and impulsive buying behavior is perceived perishability, which contradicts Vanissa et. al. (2020) and Cook and Yurchisin (2016). However, this finding is in line with Yoo (2016) which found that time pressure did not influence purchase intention in social e-commerce. Compared to the flash sale program, customers feel they have enough time to participate in the event because the offers during Harbolnas are open for 24 hours. Furthermore, the main e-commerce companies in Indonesia frequently organize sales promotional programs, such as twin dates sales programs namely 2.2, 3.3, 4.4, and so on. As a result, customers perceive 
the time pressure during Harbolnas is no longer relevant to affect their attitude toward the event and is not seen as a justification to buy impulsively.

This study finds a strong influence of hedonic shopping motivation on attitude toward sales promotion and impulsive buying behavior. These findings are in line with a previous study by Chung, Song, and Lee (2018). Specifically, Khare, Achyani, and Khattar (2014) found that hedonic shopping motivation had a significant effect on attitudes towards sales promotion programs. Meanwhile, research by Cavusoglu (2020), Kempa et al. (2020), Omid (2016), Zheng (2019), and Dey and Srivastava (2017) found that hedonic shopping motivation had a significant effect on impulsive buying behavior. They also support Iyer et al.'s (2019) meta-analytic review of impulse buying which states that hedonic shopping motivation has a positive influence on impulsive shopping behavior. Among all dimensions, fun and escapism highly reflect the respondents' hedonic shopping motivation. It seems that customers feel happy and enjoy the event, as they can escape from boredom by participating in Harbolnas. Those who feel euphoric during the Harbolnas festival will enjoy the sensation of hunting for products and feel satisfied when buying the product.

Contradicts to the prediction, COD does not lead customers to be more impulsive during Harbolnas that does not support the result of Putri et al. (2019). It may be due to several factors. Most respondents are participating in Harbolnas through Shopee and Tokopedia that offer free delivery fees and cashback if customers pay by e-wallet, so they may consider taking these offers. In addition, the study was conducted during the pandemic where government encourage cashless transactions to reduce the spread of the virus. This study, however, reports a moderating role of COD in which COD strengthens the effect of hedonic shopping motivation on impulsive buying behavior. It supports Hameed and Deeb's (2020) finding that COD moderates the beneficial effect of hedonic motivation on purchase intention. The availability of the COD option may facilitate customers who enjoy the event but do not have credit cards or e-wallet to buy products during Harbolnas. As a result, they become more impulsive during the event.

\section{Conclusion}

This study provides useful new insight into how e-commerce seeing the relation between promotion programs, hedonic shopping motivation towards, attitude towards sales promotion, and impulsive buying behavior. It also shows how COD payment methods may impact the purchase decision. The findings confirm the effect of hedonic shopping motivation on attitude toward sales promotion and impulsive buying behavior. However, it just partially supports the effect of sales promotion elements on attitude and impulsive buying behavior since only two dimensions have a significant effect on either attitude toward sales promotion or impulsive buying behavior. This study fails to prove the effect of COD on impulsive buying behavior, but it is found that this payment method may strengthen the effect of hedonic shopping motivation on impulsive buying behavior. 
As this study finds hedonic shopping motivation is the strongest driver of impulsive buying behavior, marketers should create a fun and novelty shopping experience for customers during the shopping festival. For example, they can adopt augmented reality and use persuasion phrases to give a sense of escapism to customers and urge them to buy impulsively. They also have to maintain a low price to make customers favor the event. This strategy can be performed through product bundling, spectacular discounts with the purchase of a specific quantity, and cross-selling. Ecommerce companies may also consider product segmentation by time, gender, age, and profession. As perceived scarcity only has a significant positive effect on impulsive buying behavior, which may be due to the similarity of discounted products offered in every sales promotion event, e-commerce companies may consider offering different products in each different promotional event.

\section{References}

Aggarwal, P., \& Vaidyanathan, R. (2003). Use it or lose it: purchase acceleration effects of time-limited promotions. Journal of Consumer Behaviour, 2(4), 393-403. https://doi.org/10.1002/cb.116.

Akram, U., Hui, P., Khan, M. K., Hashim, M., Qiu, Y., \& Zhang, Y. (2017). Online impulse buying on "Double Eleven" shopping festival: an empirical investigation of utilitarian and hedonic motivations. In International Conference on Management Science and Engineering Management Springer, Cham, Japan, pp. 680-692.

Akram, U., Hui, P., Khan, M. K., Yan, C., \& Akram, Z. (2018b). How website quality affects online impulse buying: moderating effects of sales promotion and credit card use. Asia Pacific Journal of Marketing and Logistics, 30(1), 235-256. https://doi.org/10.1108/APJML-04-2017-0073.

Amanah, D., \& Pelawi, S. P. (2015). Pengaruh promosi penjualan (sales promotion) dan belanja hedonis (hedonic shopping) terhadap impulsive buying produk Matahari Plaza Medan Fair. Jurnal Quanomic, 3(2), 10-18.

Amara, R. B., \& Kchaou, A. S. (2014). The role of sales promotion in inducing impulse purchases. International Journal of Management Excellence, 3(1), 362-372. https:// doi.org/ 10.17722/ijma.v3i1.144

Andani, K., \& Wahyono. (2018). Influence of sales promotion, hedonic shopping motivation, and fashion involvement toward impulse buying through a positive emotion. Management Analysis Journal, 7(4), 449-457. https://doi.org/10.15294/MAJ.V7I4.24105.

Anjum, S., \& Chai, J. (2020). Drivers of cash-on-delivery method of payment in ecommerce shopping: evidence from Pakistan. SAGE Open, 10(3), 1-14. https://doi.org/10.1177\%2F2158244020917392.

Arslan, B. (2015). The influence of credit card usage on impulsive buying. International Journal of Physical and Social Sciences, 5(7), 235-251.

Badgaiyan, A. J., \& Verma, A. (2015). Does urge to buy impulsively differ from impulsive buying behavior? Assessing the impact of situational factors. Journal 
of Retailing and Consumer Services, 22(1), 145-157. https://doi.org/10.1016/j.jretconser.2014.10.002.

Beneke, J., Brito, A., \& Garvey, K. A. (2013). Propensity to buy private label merchandise: The contributory effects of store image, price, risk, quality and value in the cognitive stream. International Journal of Retail \& Distribution Management, 43(1), 43-62. https:/ / doi.org/10.1108/IJRDM-09-2013-0175.

Bertens, K. (2018). Pengantar Etika Bisnis. Yogyakarta: Kanisius.

Burke, P. J., \& Stets, J. E. (1999). Trust and commitment through self-verification. Social Psychology Quarterly, 62(1), 347-366. https:// doi.org/10.2307/2695833.

Byun, S.-E., \& Sternquist, B. (2008). The antecedents of in-store hoarding: measurement and application in the fast fashion retail environment. International Review of Retail Distribution \& Consumer Research, 18(1), 133-147. https://doi.org/10.1080/09593960701868241.

Byun, S.-E., \& Sternquist, B. (2011). Fast fashion and in-store hoarding. Clothing and Textiles Research Journal, 29(3), 187-201. https:/ / doi.org/10.1177/0887302x11411709.

Byun, S.-E., \& Sternquist, B. (2012). Here-today-gone-tomorrow: consumer reactions to perceived limited availability. Journal of Marketing Theory and Practice, 20(2), 223-234. https:/ / doi.org/10.2753/MTP1069-6679200207.

Calvo-Porral, C., \& Lévy-Mangin, J.-P. (2017). Store brands' purchase intention: examining the role of perceived quality. European Research on Management and Business Economics, 23(2), 90-95. https://doi.org/10.1016/j.iedeen.2016.10.001.

Çavuşoğlu, S., Demirağ, B., \& Durmaz, Y. (2020). Investigation of the effect of hedonic shopping value on discounted product purchasing. Review of International Business and Strategy, https:/ / doi.org/10.1108/RIBS-04-2020-0034.

Chang, H.-J., Eckman, M., \& Yan, R.-N. (2011). Application of the Stimulus-OrganismResponse model to the retail environment: the role of hedonic motivation in impulse buying behavior. The International Review of Retail, Distribution and $\begin{array}{lll}\text { Consumer 21(3), 233-249. } & \text { Research, }\end{array}$ https:/ / doi.org/10.1080/09593969.2011.578798.

Childers, T. L., Carr, C. L., Peck, J., \& Carson, S. (2001). Hedonic and utilitarian motivations for online retail shopping behavior. Journal of Retailing, 77(1), 511535. https:// doi.org/10.1016/S0022-4359(01)00056-2.

Chung, N., Song, H. G., \& Lee, H. (2017). Consumers' impulsive buying behavior of restaurant products in social commerce. International Journal of Contemporary Hospitality Management, 29(2), 709-731, https://doi.org/10.1108/IJCHM-102015-0608.

Cialdini, R.B. (2009). Influence: Science and Practice, 5th ed. Boston: Allyn \& Bacon.

Cook, S.C., \& Yurchisin, J. (2016). Fast fashion environments: consumer's heaven or retailer's nightmare?. International Journal of Retail \& Distribution Management, 45(2), 143-157. https:/ / doi.org/10.1108/IJRDM-03-2016-0027.

Dewi, M. A. A., Nurrohmah, I., Sahadi, N., Sensuse, D. I., \& Noprison, H. (2017). Analyzing the critical factors influencing consumers' e-impulse buying behavior. 2017 International Conference on Advanced Computer Science and Information 
$\begin{array}{lll}\text { Systems } \quad \text { (ICACSIS), } & \text { (Bali, 2017), }\end{array}$ https://doi.org/10.1109/ICACSIS.2017.8355016.

Dey, D. K., \& Srivastava, A. (2017). Impulse buying intentions of young consumers from a hedonic shopping perspective. Journal of Indian Business Research, 9(4), 266-282. https://doi.org/10.1108/JIBR-02-2017-0018.

Genchev, E., \& Todorova, G. (2017). Sales promotion activities effective tool of marketing communication mix. Trakia Journal of Science, 15(1), 181-185. https://dx.doi.org/10.2139/ssrn.3089894.

Gitlin, T. (2007). Media Unlimited: How the Torrent of Images and Sounds Overwhelms Our Lives. New York, NY: Henry Holt.

Goetha, S. (2020). Analisis pengaruh scarcity message terhadap pembelian impulsif dan kaitannya dengan kompetisi konsumen ritel di Kota Kupang. Jurnal Inspirasi Ekonomi, 2(2), 33-47.

Gupta, S., \& Gentry, J.W. (2019). 'Should I buy, hoard, or hide?' - consumers' responses to perceived scarcity. The International Review of Retail, Distribution and Consumer Research, 178-197. https:// doi.org/10.1080/09593969.2018.1562955.

Gupta, Y., Sundararaghavan, P. S., \& Ahmed, M. U. (2003). Ordering policies for items with seasonal demand. International Journal of Physical Distribution \& Logistics Management, 33(1), 500-518. https:/ / doi.org/10.1108/09600030310492760.

Hair, J. F., Ringle, C. M., \& Sarstedt, M. (2011). PLS-SEM: indeed a silver bullet. Journal of Marketing Theory and Practice, 19(2), 139-151. https://doi.org/10.2753/MTP1069-6679190202.

Hair, J. F., Sarstedt, M., Hopkins, L., dan Kuppelwieser, V. G. (2014). Partial least squares structural equation modeling (PLS-SEM): An emerging tool in business research. European Business Review, 26(2), 106-121, https://doi.org/10.1108/EBR-10-2013-0128.

Halaweh, M. (2017). Intention to adopt the Cash on Delivery (COD) payment model for e-commerce transactions: An empirical study. In IFIP international conference on computer information systems and industrial management (pp. 628-637). Springer, Cham.

Halaweh, M. (2018). Cash on delivery (COD) as an alternative payment method for ecommerce transactions: analysis and implications. International Journal of Sociotechnology and Knowledge Development, 10(4), 1-12. https://doi.org/10.4018/IJSKD.2018100101.

Hameed, S., \& El-Deeb, S. (2020). Cash on delivery as a determinant of e-commerce growth in emerging markets. Journal of Global Marketing, 33(4), 242-235. https:/ / doi.org/10.1080/08911762.2020.1738002.

Harmancioglu, N., Finney, R.Z., \& Joseph, M. (2009). Impulse purchases of new products: an empirical analysis. Journal of Product \& Brand Management, 18(1), 27-37. https://doi.org/10.1108/10610420910933344.

Hawk, S. (2004). A comparison of B2B e-commerce in developing countries. Electronic Commerce

Research, $4(31)$,

181-199. https:/ / doi.org/10.1023/B:ELEC.0000027979.91972.36. 
Henseler, J., Ringle, C.M. \& Sarstedt, M. A new criterion for assessing discriminant validity in variance-based structural equation modeling. J. of the Acad. Mark. Sci. 43, 115-135 (2015). https:/ / doi.org/10.1007/s11747-014-0403-8

Hovland, C.I., Janis, I.K., \& Kelley, H.H. (1953). Communication and Persuasion, New Haven, CT: Yale University Press.

Hussain, S. \& Siddiqui, D. A. (2019). The influence of impulsive personality traits and store environment on impulse buying of consumer in Karachi. International Journal of Business Administration, 10(3), 50-73.

Ilmalana. (2012). Analisis motivasi konsumen online dalam melakukan impulse buying pada transaksi C2C commerce (Studi pada forum jual beli kaskus). (Unpublished Undergraduate Thesis). Universitas Indonesia.

Ismaya, E. (2018). Pengaruh informasi kebetulan, kelangkaan, harga diskon, dan kenikmatan yang dirasakan terhadap keinginan untuk membeli dan perilaku pembelian impulsif pada flash sale shopee (telaah pada flash sale Shopee di Indonesia). (Unpublished Undergraduate Thesis). Universitas Multimedia Nusantara.

Iyer, G.R., Blut, M., Xiao, S.H., \& Grewal, D. (2020). Impulse buying: a meta-analytic review. Journal of the Academy of Marketing Science, 48(3), 384-404. https:/ / doi.org/10.1007/s11747-019-00670-w.

Jacoby, J. (2002). Stimulus-Organism-Response reconsidered: an evolutionary step in modeling (consumer) behavior. Journal of Consumer Psychology, 12(1), 51-57. https://doi.org/10.1207/s15327663jcp1201_05.

Jin, B., \& Suh, Y.G. (2005). Integrating effect of consumer perception factors in predicting private brand purchase in a Korean discount store context. Journal of Consumer Marketing, 22(2), 62-71. https:/ / doi.org/10.1108/07363760510589226.

Jun, B. (2018). A study of consumer behavior on online shopping discount event Cyber Hot Days - in Korea. Journal of Korea Society of Digital Industry and $\begin{array}{lll}\text { Information } \quad \text { Management, } & 14(2), & 107-115 .\end{array}$ https://doi.org/10.17662/ksdim.2018.14.2.107.

Kempa, S., Vebrian, K., \& Bendjeroua, H. (2020). Sales promotion, hedonic shopping value, and impulse buying on online consumer websites. In SHS Web of Conferences (Vol. 76, p. 01052). EDP Sciences. https://doi.org/10.1051/shsconf/20207601052.

Khan, N., Hui, L.H., Chen, T.B., \& Hoe, H.Y. (2015). Impulse buying behaviour of Generation $\mathrm{Y}$ in fashion retail. International Journal of Business and Management, 11(1), 144-151. https:// doi.org/10.5539/ijbm.v11n1p144.

Khanna, P., \& Sampat, B. (2015). Factors influencing online shopping during Diwali Festival 2014: case study of Flipkart and Amazon. Journal of International Technology and Information Management, 24(2), 65-86.

Khare, A., \& Rakesh, S. (2011). Antecedents of online shopping behavior in India: an examination. Journal of Internet Commerce, 10(4), 227-244. https://doi.org/10.1080/15332861.2011.622691.

Khare, A., Achtani, D., \& Khattar, M. (2014). Influence of price perception and shopping motives on Indian consumers' attitude towards retailer promotions in 
malls. Asia Pacific Journal of Marketing and Logistics, 26(2), 272-295. https:/ / doi.org/10.1108/ APJML-09-2013-0097.

Kosyu, D. A., Hidayat, K., \& Abdillah, Y. (2014). Pengaruh hedonic shopping motives terhadap shopping lifestyle dan impulse buying (survei pada pelanggan outlet Stradivarius di Galaxy Mall Surabaya). Jurnal Administrasi Bisnis, 14(2), 1-7.

Kotler, P., \& Keller, K.L. (2016). Marketing Management, 16th ed.. Upper Saddle River, NJ: Pearson.

Kristofferson, K., McFerran, B., Morales, A. C., \& Dahl, D. W. (2017). The dark side of scarcity promotions: how exposure to limited-quantity promotions can induce aggression. Journal of Consumer Research, 43(5), 683-706. https://doi.org/10.1093/jcr/ucw056.

Kwon, H. J., \& Brinthaupt, T. M. (2015). The motives, characteristics and experiences of US Black Friday shoppers. Journal of Global Fashion Marketing, 6(4), 292-302. https:/ / doi.org/ 10.1080/20932685.2015.1070681.

Liu, Y., Zhang, X., Zhang, Y., \& Qiu, C. (2019). Research on influencing factors of consumer shopping behavior in online shopping festival. In 2019 Annual Conference of the Society for Management and Economics (Vol. 4, pp. 35-42). The Academy of Engineering and Education. https:/ / doi.org/10.35532/JSSS.V4.007.

Madahi, A., Sukati, I., Mazhari, M.Y., \& Rashid, W.N. (2012). Consumer decision making styles amongst young generation in Malaysia. European Journal of Social Sciences, 30(2), 263-275.

Mathur, P., \& Bhakar, S. S. (2019). Psychological antecedents and impulsive buying in online shopping. International Journal of Recent Technology and Engineering (IJRTE) 8(1S4), 15-18.

Mihic, M., \& Kursan Milakovic, I. (2017). Examining shopping enjoyment: Personal factors, word of mouth and moderating effects of demographics. Economic research - Ekonomska istra?ivanja, 30(1), 1300-1317.

Morales, A., McFerran, B., Dahl, D. W., \& Kristofferson, K. (2014). The dark side of marketing tactics: scarcity promotions induce aggressive behavior. In The Advances in Consumer Research (Vol. 42, pp. 556-557). June Cotte and Stacy Wood, Duluth, MN : Association for Consumer Research.

Mu, H., \& Moon, T. (2016). Impulse purchase intention of Chinese customers at the large scale online promotion day: focus on intrinsic and extrinsic motivation perspective. The Journal of Internet Electronic Commerce Research, 16(5), 81-98.

Muna, N., Fatmasari, F., \& Murti, A.K. (2017). Exploring design needs of wifimarketing as promotional strategy for mall industry. Business Creative Movement Journal, 4(1). https://doi.org/10.2991/bcm-17.2018.6.

Nandha, O., Andriani, K., \& Edriana, P. (2017). The effect of store environment, availability of money and time, hedonic consumption tendency on emotional states and its impact on impulse buying behaviour. Russian Journal of $\begin{array}{llll}\text { Agricultural and Socio-Economic } & \text { 5ciences, 63(3), }\end{array}$ https://doi.org/10.18551/rjoas.2017-03.09. 
Nugroho, A., \& Magnadi, R. H. (2018). Pengaruh kualitas layanan terhadap kepuasan pelanggan jasa pengiriman Lazada Express saat Harbolnas di e-commerce. Diponegoro Journal of Management, 7(4), 33-43.

Omid, M. (2016). How sales promotions influence impulse buying: The critical role of affect and cognition. (Master Thesis). Universite Laval: Québec, Canada.

Parmar, G., \& Chauhan, J. (2018). Factors affecting online impulse buying behavior. International Journal of Education and Management Studies, 8(3), 358-361.

Phau, I., \& Lo, C.C. (2004). Profiling fashion innovators: a study of self-concept, impulse buying. Journal of Fashion Marketing and Management: An International Journal, 8(4), 399-411. https:/ / doi.org/10.1108/13612020410559993.

Prashar, S., Raja, B.A., Parasaran, V.S., \& Venna, V.K. (2015). Factor prompting impulse buying behaviour: shoppers in Dubai. Asian Journal of Business Management, 5(3), 5-15. https:// doi.org/10.13106/ eajbm.2014.vol5.no3.5.

Pratama, Aditya M. O. (2019). Pengaruh Harga, Distribusi, Dan Persepsi Terhadap Proses Keputusan Pembelian Pakaian Impor Pada Masyarakat Seberang Ulu Palembang. Palembang: Universitas Muhamadiyah Palembang.

Putri, Y.E., Wiryono, S.K., Nainggolan, Y.A., \& Cahyono, T.D. (2019). Method of payment adoption in Indonesia e-commerce. The Asian Journal of Technology Management, 12(2), 94-102.

Rahmawan, M. F., \& Hanifa, F. H. (2016). Pengaruh strategi penetapan harga diskon Harbolnas dan web quality 4.0. lazada.co.id terhadap keputusan pembelian. Prosiding Seminar Nasional Penelitian dan PKM Sosial, Ekonomi dan Humaniora, 6(1), 35-40.

Rajput, S., Chauhan, R., Kaveeshwar, D., Sisiodiya, P., Sharma, N., Jain, N., \& Panjnani, L. (2016). Effect of credit cards usage on impulse buying behavior: a study of mall shoppers in Gwalior Region. In S.S. Bhakar \& G. Mathur (Eds.). A Systematic Guide from Research to Manuscript: Prestige Institute of Management Gwalior. (pp. 259-268). New Dehli (India): Bharti Publications.

Robert, J. A., \& Jones, E. (2001). Money attitudes, credit card use, and compulsive buying among American college students. Journal of Consumer Affairs, 35(2), 213-240. https:/ / doi.org/10.1111/j.1745-6606.2001.tb00111.x.

Rook, D. W. (1987). The impulse buying. Journal of Consumer Research, 14(2), 189199, https://doi.org/10.1086/209105.

Rook, D.W., \& Fisher, R.J. (1995). Normative influences on impulsive buying behaviour. Journal of Consumer Research, 22(3), 305-313. https://doi.org/10.1086/209452.

Rouibah, K. (2015). Electronic payment systems use and satisfaction in an Arabic country: evidence from Kuwait. Issues in Information Systems, 16(2), 149-160. https://doi.org/10.48009/2_iis_2015_149-160.

Scarpi, D., Pizzi, G., \& Visentin, M. (2014). Shopping for fun or shopping to buy: is it different online and offline?. Journal of Retailing and Consumer Services, 21(3), 258-267. https:/ / doi.org/10.1016/j.jretconser.2014.02.007.

Setyaningrum, F. Y., Arifin, Z., \& Yulianto, E. (2016). Pengaruh hedonic motives terhadap shopping lifestyle dan impulse buying (survei pada konsumen 
Superindo Supermarket yang melakukan impulse buying). Jurnal Admistrasi Bisnis, 37(1), 97-104.

Shamout, M. D. (2016). The impact of promotional tools on consumer buying behavior in retail market. International Journal of Business and Social Science, 7(1), 75-85.

Siregar, N. F., \& Rini, Q. K. (2019). Regulasi diri dan impulsive buying terhadap produk fashion pada remaja perempuan yang berbelanja online. Jurnal Psikologi, 12(2), 213-224. https:// doi.org/10.35760/psi.2019.v12i2.2445.

Snoj, B., Korda, A., \& Mumel, D. (2004). The relationships among perceived quality, perceived risk and perceived product value. Journal of Product \& Brand Management, 13(3), 156-167. https:/ / doi.org/10.1108/10610420410538050.

Statista Research Department (2020). Global retail e-commerce sales 2014-2023. Retrieved Oct 20, 2020, from https://www.statista.com/statistics/379046/worldwide-retail-e-commercesales/\#: :text=Global\%20retail\%20e\%2Dcommerce\%20sales\%202014\%2D2023\& text $=$ In $\% 202019 \% 2$ C \% 20retail \%20e\%2Dcommerce,most \%20popular\%20online \% 20activities \%20worldwide.

Tandon, U., \& Kiran, R. (2018). Study on drivers of online shopping and significance of cash-on-delivery mode of payment on behavioural intention. International $\begin{array}{llll}\text { Journal of Electronic } & \text { Business, }\end{array}$ https://doi.org/10.1504/ijeb.2018.095959.

Tokatli, N. (2008). Global sourcing: insights from the global clothing industry-the case of Zara, a fast fashion retailer. Journal of Economic Geography, 8(1), 21-38. https://doi.org/10.1093/jeg/lbm035.

Vannisa, D., Fansuri, A., \& Ambon, I. M. (2020). The effect of flash sale program on shopping enjoyment and impulse buying on flash sale on $\mathrm{C} 2 \mathrm{C}$ e-commerce. International Journal of Scientific \& Technology Research Volume, 9(4), 2534-2539.

Verhallen, T. M. M., \& Robben, H. S. J. (1994). Scarcity and preference: an experiment on unavailability and product evaluation. Journal of Economic Psychology, 15(2), 315-331. https:/ / doi.org/10.1016/0167-4870(94)90007-8

Wu, B., Deng, X., \& Cui, X. (2020). Cash on delivery or online payment: mobile channel, order size and payment methods. Journal of Contemporary Marketing Science, 3(2), 225-242. https:/ / doi.org/10.1108/JCMARS-12-2019-0048.

$\mathrm{Xu}, \mathrm{Y}$. (2007). Impact of store environment on adult generation $\mathrm{Y}$ consumers' impulse buying. Journal of Shopping Center Research, 14(1), 39-56.

Yoo, J. (2016). The Effects of product popularity and time pressure on consumer responses in social commerce. The e-Business Studies, 17(2), 127-145.

Yu, C., \& Bastin, M. (2010). Hedonic shopping value and impulse buying behavior in transitional economies: a symbiosis in the Mainland China marketplace. Journal of Brand Management, 18(1), 105 - 114. https:/ / doi.org/10.1057/bm.2010.32

Zaltman, G. (2000). Consumer researchers: Take a hike!. Journal of Consumer Research, 26(1), 423-428. https:/ / doi.org/10.1086/209573.

Zheng, X., \& Lee, M. K. O. (2016). Exploring consumers' impulse buying behavior on social commerce platform: the role of parasocial interaction. International Journal 
of Information

Management.

36(3),

333-347.

https://doi.org/10.1016/j.ijinfomgt.2015.11.002.

Zheng, X., Men, J., Yang, F., \& Gong, X. (2019). Understanding impulse buying in mobile commerce: An investigation into hedonic and utilitarian browsing. International Journal of Information Management, 48(1), 151-160. https://doi.org/10.1016/j.ijinfomgt.2019.02.010. 